\title{
Immune response in nonspecific mastitis: What can it tell us?
}

\author{
F. N. Souza, ${ }^{1,2,3,4 *}$ M. G. Blagitz, ${ }^{1,5 *}$ C. F. Batista, ${ }^{1}$ P. V. Takano, ${ }^{2}$ R. G. Gargano, ${ }^{1}$ S. A. Diniz, ${ }^{6}$ M. X. Silva, ${ }^{6}$ \\ J. A. Ferronatto, ${ }^{1}$ K. R. Santos, ${ }^{1}$ M. B. Heinemann, ${ }^{2}$ S. De Vliegher, ${ }^{3}$ and A. M. M. P. Della Libera ${ }^{1}$ \\ ${ }^{1}$ Veterinary Clinical Immunology Research Group, Departamento de Clínica Médica, Faculdade de Medicina Veterinária e Zootecnia, \\ Universidade de São Paulo, São Paulo 05508-270, Brazil \\ ${ }^{2}$ Departamento de Medicina Veterinária Preventiva e Saúde Animal, Faculdade de Medicina Veterinária e Zootecnia, Universidade de São Paulo, \\ São Paulo 05508-270, Brazil \\ ${ }^{3}$ M-team and Mastitis and Milk Quality Research Unit, Department of Reproduction, Obstetrics and Herd Health, Faculty of Veterinary Medicine, \\ Ghent University, Salisburylaan 133, Merelbeke 9820, Belgium \\ ${ }^{4}$ Programa de Pós-Graduação em Ciência Animal, Universidade Federal da Paraíba, Areia 58397-000, Brazil \\ ${ }^{5}$ Programa de Pós-Graduação em Saúde, Bem-estar e Produção Animal Sustentável na Fronteira Sul, Universidade Federal da Fronteira Sul, \\ Realeza 85770-000, Brazil \\ ${ }^{6}$ Departamento de Medicina Veterinária Preventiva, Escola de Veterinária, Av. Presidente Antônio Carlos, 6627, Belo Horizonte 30123-970, Brazil
}

\begin{abstract}
We analyzed a large number of immune response parameters from quarter milk samples with distinct bacteriological and quarter somatic cell count (qSCC) statuses. Furthermore, we sought to explore and identify displayed immune response patterns in milk samples from mammary glands with nonspecific mastitis. Thus, 92 quarter milk samples from 28 cows were stratified into 4 groups, as follows: (1) 49 culture-negative control quarters with a low qSCC $\left(<1 \times 10^{5}\right.$ cells $\left./ \mathrm{mL}\right)$ from 19 dairy cows (so-called healthy quarters); (2) 15 culture-negative quarters with high qSCC $\left(>2 \times 10^{5}\right.$ cells $/ \mathrm{mL}$; so-called quarters with nonspecific mastitis) from 10 dairy cows; (3) 8 culture-positive quarters with low qSCC (noninflammatory quarters with low qSCC) from 5 dairy cows; and (4) 20 culture-positive quarters with high qSCC (so-called truly infected quarters) from 8 dairy cows. Using flow cytometry, we evaluated the percentage of milk neutrophils and their viability, intracellular reactive oxygen species production, phagocytosis, and the expression of CD62L, CD11b, and CD44 for each of the 4 quarter strata. Furthermore, the percentage of monocyte/macrophages, $\mathrm{B}$ cells, and $\mathrm{T}$ lymphocyte subsets were evaluated by flow cytometry. Milk samples from bacteriologically negative quarters (both with a low and elevated qSCC) had a lower qSCC than those with bacteriologically positive outcomes (both with a low and elevated qSCC). As expected, the healthy quarters showed the lowest percentage of neutrophils and also showed a higher percentage of
\end{abstract}

Received May 25, 2019.

Accepted January 26, 2020.

*These authors contributed equally to this work.

†Corresponding author: nogueirasouza@yahoo.com.br milk monocytes/macrophages and lower percentage of T lymphocytes than truly infected quarters. The most prominent result of the present study is that quarters with nonspecific mastitis showed the highest percentage of milk $\mathrm{CD} 4^{+} \mathrm{T}$ lymphocytes. The healthy quarters had a lower percentage of apoptotic neutrophils than noninflammatory and truly infected quarters, although it did not differ from those from the quarters with nonspecific mastitis. Our study supports the role of differential cell counting in the diagnosis of mastitis, as the milk leukocyte populations markedly fluctuate under healthy and inflammatory conditions. Furthermore, an increase in milk $\mathrm{CD} 4^{+} \mathrm{T}$ cells was associated with nonspecific mastitis, suggesting an increase in this leukocyte subpopulation is correlated with low bacterial shedding. Our study allows us to go further in our understanding of mammary gland immunity, providing further insights on potential protective mammary gland immunity, which we hypothesize can open new avenues for the development of novel targets that can promote bovine udder health.

Key words: mastitis, intramammary infection, differential leukocyte count, somatic cell count, dairy cow

\section{INTRODUCTION}

Mastitis is the costliest disease in dairy production with important public health and animal well-being concerns (Oliver et al., 2011; Stevens et al., 2016). Still, the definition of mastitis is not always consistent, and often used interchangeably with IMI. Intramammary infection requires the presence of a pathogen, although mastitis entails inflammation but not always infection of the mammary gland (Andersen et al., 2010). Thus, routine diagnosis of mastitis is based on the indicators of inflammation, and consequently the milk SCC has 
long been included as a component of the definition of mastitis (Pyörälä, 2003). Somatic cell count measures all somatic cells in milk; nevertheless, it does not distinguish the different cell populations present. Thus, it has been proposed that differential cell counting (DCC) could provide a more reliable inflammatory status of the mammary gland (Pyörälä, 2003; Koess and Hamann, 2008; Takano et al., 2018).

Culture of approximately 25 to $50 \%$ of all milk samples with high SCC does not yield bacterial growth (Makovec and Ruegg, 2003; Taponen et al., 2009; Souza et al., 2016). In the last few years, growing evidence is available that no-growth of mastitis pathogens from quarters with subclinical (Souza et al., 2016) and clinical mastitis (Pinzón-Sánchez and Ruegg, 2011) is associated with higher spontaneous bacteriological cure rates. In other words, in these cases, the milk somatic cells could be (more) effective in reducing the number of bacteria and could consequently reduce the likelihood of isolating the viable pathogen, suggesting the immune system is capable of overcoming the infection (Pinzón-Sánchez and Ruegg, 2011; Souza et al., 2016). We hypothesize that the likelihood of bacterial shedding correlates with the immune response of quarters within cows. Mapping the immune response by measuring specific immune parameters (i.e., by comparing parameters from samples with distinct bacteriological and quarter milk SCC statues) will allow identification of potential immune parameters that are potentially correlated with a successful pathogen-host immune response. This could eventually reveal an immune response pattern that is able to improve existing mastitis prevention and control programs.

Furthermore, although milk leukocyte patterns in mammary glands with distinct bacteriological and quarter SCC (qSCC) statuses have been studied using microscopic DCC independent of the mastitis-causing pathogen (Pilla et al., 2012), we wanted to deepen our understanding of the immunological profile of quarters under healthy and inflammatory conditions. For instance, using flow cytometry, we provide detailed information on lymphocyte subsets and several PMN functions, including viability, reactive oxygen species (ROS) production, phagocytosis, and expression of adhesion molecules (i.e., $\beta$-chain of $\beta_{2}$-integrin, one of the 3 endothelial-selectin ligands, and L-selectin). Thus, to the best of our knowledge, this study is the first to compare a large number of immune response parameters from quarter milk samples with distinct bacteriological and qSCC results independent of the mastitis-causing pathogen, when present.

Thus, in the present study we sought to explore and identify displayed immune response patterns specific for milk samples from mammary glands suffering from nonspecific mastitis (i.e., milk samples with high qSCC and microbiological negative results). Furthermore, our study provided detailed immunological profile of quarters under healthy and inflammatory conditions.

\section{MATERIALS AND METHODS}

\section{Samples and Sample Strata}

Twenty-eight clinically healthy Holstein dairy cows at different lactation stages were enrolled from one commercial herd located at Tambaú city, Brazil. First, milk samples from 112 individual mammary quarters were aseptically collected for microbiological analysis as described by the National Mastitis Council (1999). Then, milk samples were collected in sterile plastic bottles by hand milking for the qSCC $(40 \mathrm{~mL})$ and flow cytometric analyses ( $1 \mathrm{~L}$ of milk). Samples were kept at $4^{\circ} \mathrm{C}$ until arriving at the laboratory.

Quarters with qSCC between $>1 \times 10^{5}$ and $<2 \times$ $10^{5}$ cells $/ \mathrm{mL}$ were excluded $(\mathrm{n}=20)$, as there are some variations in widely accepted qSCC thresholds (Schepers et al., 1997; Pyörälä, 2003; Bansal et al., 2005; Schwarz et al., 2010).

Based on bacteriological culture and qSCC results, the remaining 92 samples were stratified into 4 strata, as follows: (stratum 1) 49 culture-negative control quarters from 19 dairy cows with no abnormal secretions in the strip cup test and a qSCC $<1 \times 10^{5}$ cells $/ \mathrm{mL}$ (so-called healthy quarters), using the threshold for qSCC described by Bansal et al. (2005) and Schwarz et al. (2010) in uninfected quarters; (stratum 2) 15 culture-negative quarters from 10 dairy cows with high qSCC $\left(>2 \times 10^{5}\right.$ cells $/ \mathrm{mL}$; so-called nonspecific mastitis), as the threshold for qSCC proposed by Schepers et al. (1997) and Schukken et al. (2003); (stratum 3) 8 culture-positive quarters from 5 dairy cows with low qSCC $\left(\leq 1 \times 10^{5}\right.$ cells $/ \mathrm{mL}$; so-called noninflammatory infected quarters); and finally (stratum 4) 20 culturepositive quarters from 8 dairy cows with high qSCC $\left(>2 \times 10^{5}\right.$ cells $/ \mathrm{mL}$; so-called truly infected quarters with high qSCC).

Afterward, samples were randomized and codified, and the additional milk analyses were carried out without knowledge of the status of the quarter. This study complied with the Ethical Principles in Animal Research (Brazil, 2008) and was approved by the Bioethics Commission of the Faculty of Veterinary Medicine and Animal Science University of São Paulo.

\section{Bacteriological Culture}

The bacteriological culture was performed by culturing $0.01 \mathrm{~mL}$ of each milk sample on $5 \%$ sheep blood 
agar plates. The plates were incubated for $72 \mathrm{~h}$ at $37^{\circ} \mathrm{C}$, followed by observation of colony morphology, Gram staining, and biochemical testing (Oliver et al., 2004). A sample was considered culture-negative if no growth was observed (no colony from a 0.01-mL sample; $<100$ $\mathrm{cfu} / \mathrm{mL})$.

\section{Determination of the SCC}

For SCC measurement, milk samples were collected in tubes containing microtablets of bronopol (2-bromo2-nitropane-1,3-diol) and were carried out using an automated somatic cell counter (Somacount 300, Bentley Instruments, Chaska, MN).

\section{Separation of Milk Cells}

For flow cytometric analysis, $1 \mathrm{~L}$ of milk from each mammary quarter was diluted with $1 \mathrm{~L}$ of PBS, and milk cells were separated as previously described by Koess and Hamann (2008) and Della Libera et al. (2015). The cells were placed in $1 \mathrm{~mL}$ of RPMI-1640 nutrition medium (R7638, Sigma-Aldrich, St. Louis, MO) supplemented with $10 \%$ fetal bovine serum (Cultilab, Campinas, Brazil) and counted using a Neubauer chamber. The cell viability was first assessed using trypan blue exclusion. The number of cells per quadrant was similar during counting in the Neubauer chamber, which indicates the homogeneous distribution of milk cells. Afterward, we gently mixed the cell suspension before taking an aliquot for every assay to ensure the homogeneous distribution of cells. The milk cells were then diluted with the nutrition medium and $10 \%$ fetal bovine serum to a concentration of $2 \times 10^{6}$ viable cells/ $\mathrm{mL}$.

\section{Enumeration of Lymphocyte Subpopulations}

The cells were washed with PBS and stained for CD21, CD3, CD4, and CD8 for $30 \mathrm{~min}$ at room temperature. The identification of lymphocytes subsets was based on the their cytoplasmatic granularity and mean fluorescence intensity following 2-step fluorescent immunolabeling with primary anti-bovine $\mathrm{mAb}$ and the secondary antibody coupled to the long-wavelength fluorescent probes (Table 1). After washing with PBS, the cells were incubated for $30 \mathrm{~min}$ at room temperature with the secondary antibodies. The cells were then washed with PBS and immediately analyzed by flow cytometry (FACSCalibur, BD Bioscience, San Jose, CA). Here, 20,000 milk cells, excluding most of the cell debris, were analyzed in each sample. An unstained control, secondary antibody control, and single stained milk samples were also prepared as compensation con- trols. FlowJo software (TreeStar Inc., Ashland, OR) was used to examine the data.

\section{Identification of Neutrophils and Monocytes/Macrophages}

Milk neutrophils and monocyte/macrophages were differentiated from other cells by indirect fluorescent labeling by incubating for $30 \mathrm{~min}$ at room temperature with unlabeled primary mAb (Table 1). A gating strategy was used to differentiate granulocytes and monocytes (Figure 1) because CD14, although abundantly expressed on the surface of monocytes, can also be expressed to a lesser extent on bovine PMN (IbeaghaAwemu et al., 2008; Piepers et al., 2009), as previously described (Blagitz et al., 2017). Next, $1 \mathrm{~mL}$ of PBS was added to the cell suspension and centrifuged at 400 $\times g$ for 8 min. Finally, a labeled secondary antibodies (Table 1) were added and incubated for $30 \mathrm{~min}$ at room temperature in the dark to visualize CH138A and CD14 binding. An unstained control, secondary antibody control, and single stained milk samples were also prepared as compensation controls. The neutrophils were identified based on the cells' cytoplasmic granularities and CH138A positivity (Figure 1), as previously described by Piepers et al. (2009), Blagitz et al. (2013), and Blagitz et al. (2015a). A subpopulation of $\mathrm{CH}_{138 \mathrm{~A}^{+}}$cells with low SSC-H property were excluded, representing nonspecific binding of $\mathrm{CH}_{138 \mathrm{~A}^{+}}$to milk cells and cellular debris (Figure 1), as proposed by Piepers et al. (2009). The monocytes/macrophages were identified based on CD14 positivity after excluding CH138A ${ }^{+}$ cells (Figure 1). Here, 20,000 milk cells, excluding most of the cell debris, were analyzed in each sample. FlowJo software (TreeStar Inc.) was used to examine the data.

\section{Detection of PMN Apoptosis by Flow Cytometry}

The death of the neutrophils $\left(\mathrm{CH} 138^{+}\right)$was measured by dual labeling with annexin $\mathrm{V}$ and propidium iodide (PI; K2350, APOPTEST-FITC, Dako Cytomation, Mijdrecht, the Netherlands) and flow cytometry analysis as previously described (Della Libera et al., 2015; Santos et al., 2017). The milk PMN were identified using $\mathrm{mAb}$, as described above.

To analyze the data, scatterplots were generated for the gated PMN. The living, nonapoptotic cells were negative for the fluorescein isothiocyanate (FITC)labeled annexin V and PI staining. The cells that were reactive with the FITC-labeled annexin $\mathrm{V}$ but negative for PI staining were classified as apoptotic cells (Della Libera et al., 2015). The necrotic subpopulation was positive for both FITC-labeled annexin V and PI staining. 
Souza et al.: IMMUNE RESPONSE IN NONSPECIFIC MASTITIS

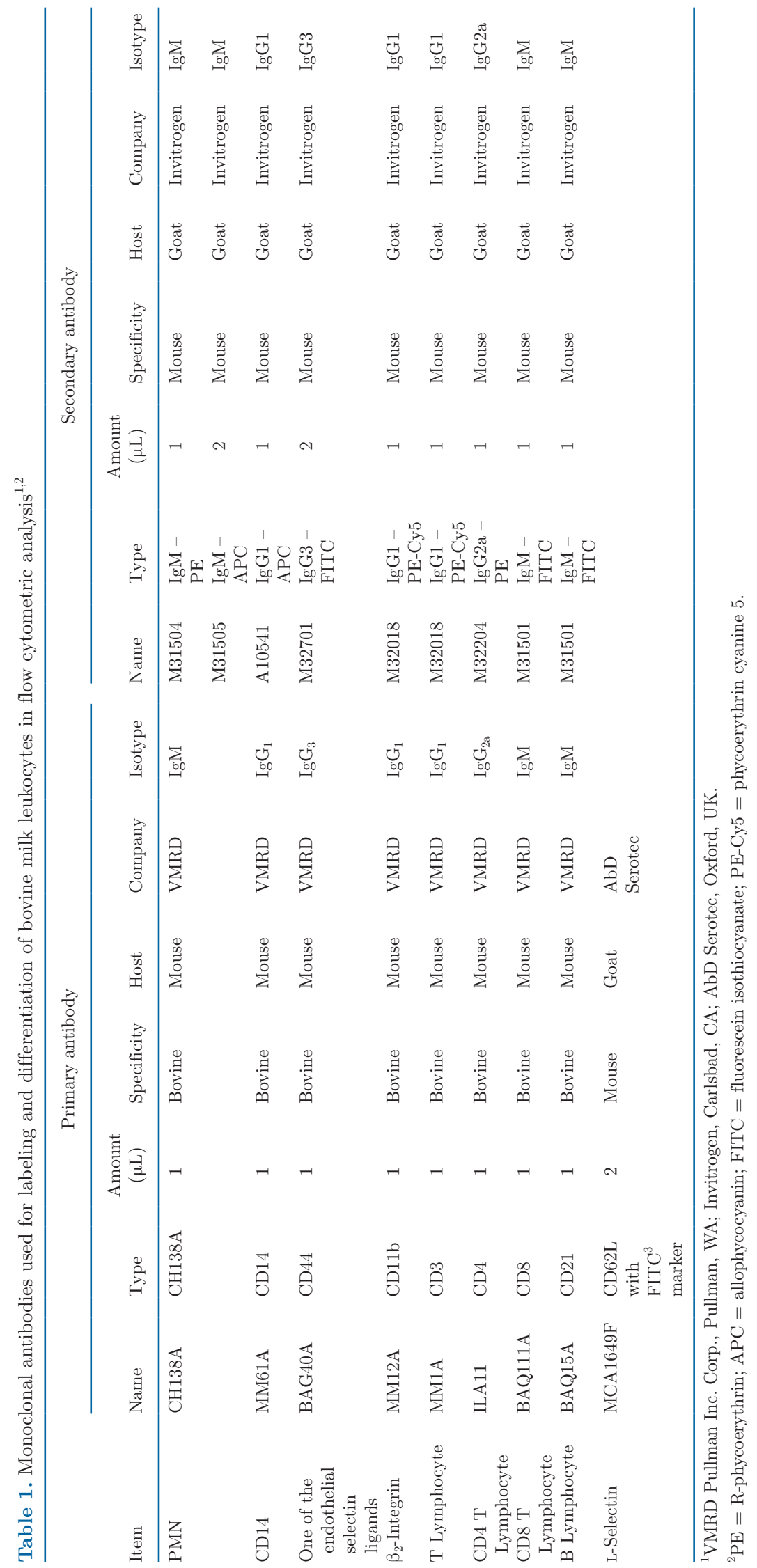



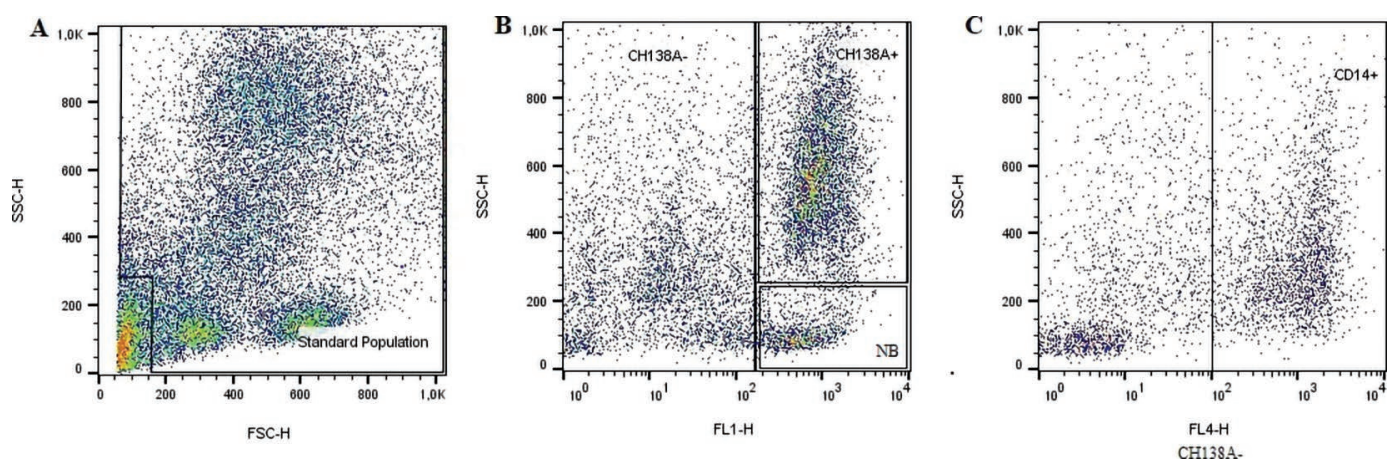

Figure 1. Successive gating scheme for identifying milk PMN $\left(\mathrm{CH} 138 \mathrm{~A}^{+}\right.$cells $)$and monocytes/macrophages $\left(\mathrm{CH} 138 \mathrm{~A}^{-} / \mathrm{CD} 14^{+}\right)$. Recordings of scatter angle light scatter (SSC-H) versus fluorescent properties (FL1-H; CH138A-fluorescein isothiocyanate) were performed on a gated standard population excluding most debris (A), which allowed us to identify PMN based on their cytoplasmatic granularity and mean fluorescence intensity following a 2-step fluorescent immunolabeling protocol using primary anti-bovine monoclonal antibody specific for PMN identification (CH138A) and secondary antibodies coupled to long-wavelength fluorescent probe (FL1-H; B). At, this moment, we also excluded PMN by gat-

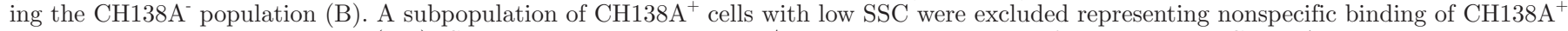
to cellular debris and milk cells (NB). Subsequently, the monocytes/macrophages were identified within the $\mathrm{CH}_{138 \mathrm{~A}^{-}}$population based on mean fluorescence intensity following a 2-step fluorescent immunolabeling protocol using primary anti-bovine monoclonal antibody specific for monocyte/macrophage identification (CD14) and secondary antibodies coupled to long-wavelength fluorescent probe (FL4-H; allophycocyanin).

\section{Intracellular ROS Production}

Intracellular ROS production was evaluated by flow cytometry using 2', $7^{\prime}$-dichlorofluorescein diacetate (D6883, Sigma-Aldrich) as a probe (Hasui et al., 1989). An unstained control and single stained samples were also prepared as compensation controls. For this assay, 10,000 gated PMN were analyzed in each milk sample. FlowJo software (TreeStar Inc.) was used to examine the data.

\section{Preparation of PI-Labeled Bacteria}

The preparation of PI-labeled Staphylococcus aureus (ATCC 25923) was performed as proposed by Hasui et al. (1989), with some modifications described by Blagitz et al. (2013, 2015a,b).

\section{Phagocytosis Assay}

The unopsonized phagocytosis assay was carried out by flow cytometry using PI-labeled Staphylococcus aureus, as previously described by Hasui et al. (1989). Briefly, $2 \times 10^{5}$ viable milk cells were incubated with $100 \mu \mathrm{L}$ of heat-killed, PI-labeled S. aureus for $30 \mathrm{~min}$ at $37^{\circ} \mathrm{C}$. Thereafter, $2 \mathrm{~mL}$ of $3 \mathrm{~m} M$ EDTA was added to substantially decrease the number of adherent bacteria to the leukocyte membrane that could be mistakenly be recognized as ingested (Batista et al., 2018), and after centrifugation at $400 \times g$ for $10 \mathrm{~min}$ at $4^{\circ} \mathrm{C}$, the leukocytes were resuspended in $300 \mu \mathrm{L}$ of PBS and examined by flow cytometry (FACSCalibur, BD Bioscience, San Jose, CA). An unstained control and single stained samples were also prepared as compensation controls.
At least 20,000 cells were analyzed in each sample of milk. The FlowJo TreeStar software (TreeStar Inc.) was used to examine the data.

\section{Expression of L-Selectin, $\beta_{2}$-Integrin, and CD44}

The identification of PMN expressing $\beta$-chain of $\beta_{2}$-integrin (CD11b), one of the 3 endothelial-selectin (E-selectin) ligands (CD44), and L-selectin (CD62L) was carried out by flow cytometry (FACSCalibur, BD Bioscience) as previously described (Della Libera et al., 2015). An unstained control, secondary antibody control, and single stained samples were also prepared as compensation controls. For this assay, 10,000 gated neutrophils cells were analyzed in each sample. The FlowJo TreeStar software (TreeStar Inc.) was used to examine the data.

\section{Statistical Methods}

First, the Kolmogorov-Smirnov test was performed to evaluate the normality and homoscedasticity of the different outcome parameters. Then, those data that did not present normality or homoscedasticity were submitted to base-10 logarithmic (SCC; percentage of T and B cells; percentage of apoptotic, viable and necrotic PMN; percentage and intensity of ROS production by PMN; intensity of phagocytosis by PMN, percentage and expression of CD44 by PMN, and expression of CD11b by PMN) or angular transformation (percentage of $\mathrm{CD} 4^{-} \mathrm{CD} 8^{+}, \mathrm{CD} 4^{+} \mathrm{CD} 8^{-}$, and $\mathrm{CD} 4^{-} \mathrm{CD} 8^{-} \mathrm{T}$ cells) according to the type of response. Subsequently, the data were analyzed using a multivariate ANOVA. 
The ANOVA test for comparison of the means used was the Duncan test. As transformation of the percentage of $\mathrm{CH}_{138 \mathrm{~A}^{+}}$cells and the percentage of $\mathrm{CD} 44^{+}$ by PMN were not possible to get normally distributed data, the Kruskal-Wallis test was applied. The model was carried out with cow as a random effect to take into account potential clustering of quarters within cows. The statistical analysis were performed using the InfoStat statistical software version 2018 (Di Rienzo et al., 2018). The mean and standard error of mean of the original variable were retained. The mean and the standard error of the original variable were retained to improve the interpretation of the results. The significance was set at $P \leq 0.05$.

\section{RESULTS}

\section{SCC and Bacteriological Analysis}

The results of the logarithm milk qSCC are presented in Figure 2. Milk samples from bacteriologically negative quarters (both with a low and elevated qSCC) had a lower qSCC than those with bacteriologically positive outcomes (both with a low and elevated qSCC). Corynebacterium bovis were isolated from all noninflammatory infected quarters (stratum 3). Streptococcus dysgalactiae and C. bovis were isolated from $55 \%(\mathrm{n}=$ $11)$ and $45 \%(\mathrm{n}=9)$, respectively, of the truly infected quarters (stratum 4).

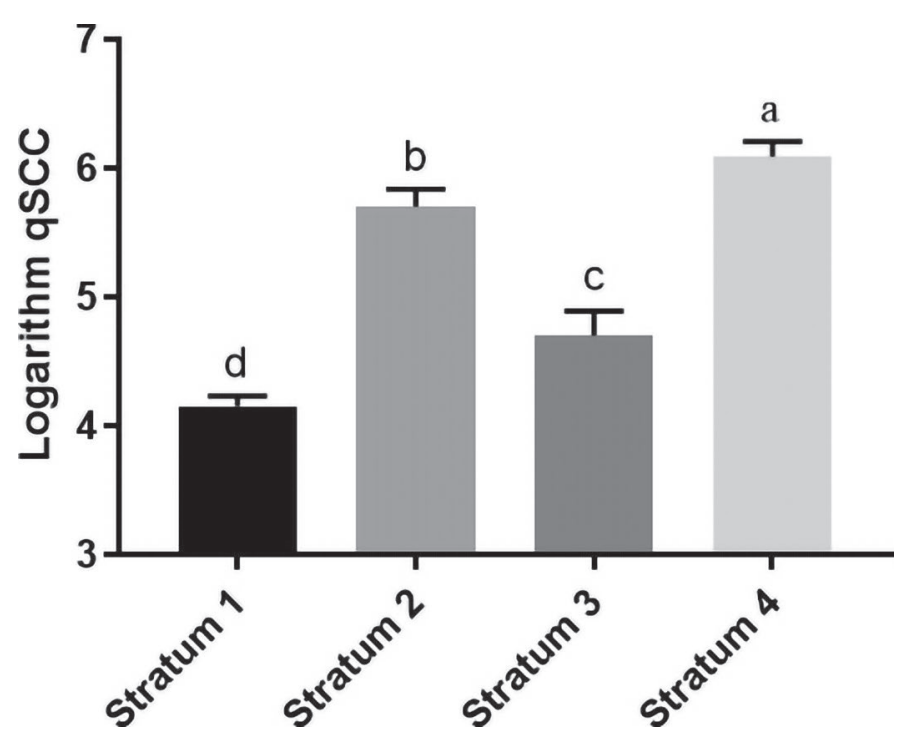

Figure 2. Logarithm quarter milk somatic cell count (qSCC) from healthy quarters (bacteriologically negative with low qSCC; stratum 1), nonspecific mastitis (bacteriologically negative with high qSCC; stratum 2), and noninflammatory (bacteriologically positive with low qSCC; stratum 3) and truly (bacteriologically positive with high qSCC; stratum 4) infected quarters. Different letters indicate $P \leq$ 0.0001. Results are reported as mean \pm SEM.

\section{Percentage of Milk PMN, Monocyte/Macrophage, and Lymphocyte Subsets}

Overall, the results of the percentage of the distinct milk leukocyte subpopulations are summarized in Table 2 , and their fluctuation in comparison with healthy mammary glands is shown in Figure 3. The healthy quarters (stratum 1) presented the lowest percentage of PMN and T lymphocytes $\left(\mathrm{CD}^{+}\right)$, in contrast to the highest percentage of milk monocytes/macrophages. The percentage of monocytes/macrophages was also higher in noninflammatory infected quarters (stratum 3 ) than truly infected quarters (stratum 4). The percentage of B cells was not statistically related to qSCC and bacteriological statuses. The percentage $\mathrm{CD} 8^{+} \mathrm{T}$ lymphocytes was highest in truly infected quarters, followed by the nonspecific mastitis (stratum 2) and noninflammatory infected quarters, in contrast to the healthy quarters, which showed the lowest level. The percentage of $\mathrm{CD} 4^{+} \mathrm{T}$ lymphocytes was the only observation with a difference in the percentage between strata 2 and the other strata. Furthermore, there is a tendency toward a higher CD4:CD8 ratio in quarters with nonspecific mastitis in comparison to healthy quarters $(P=0.06)$. The percentage of $\mathrm{CD} 4^{-} \mathrm{CD} 8^{-} \mathrm{T}$ lymphocytes was highest in truly infected quarters, followed by quarters with nonspecific mastitis and healthy quarters, in contrast to the noninflammatory quarters, which presented the lowest level.

\section{Milk PMN Functions}

The results of function of milk PMN are summarized in Table 3. The healthy quarters also had a lower percentage of apoptotic PMN than bacteriologically positive quarters (strata 3 and 4), although it did not differ from those from nonspecific mastitis. There was no relation between bacteriological and qSCC statuses and phagocytosis, intracellular ROS production, and expression of adhesion molecules by milk PMN.

\section{DISCUSSION}

Differential cell counts can be obtained by light microscopy and flow cytometry. Nonetheless, the accuracy of flow cytometry is related to the difficulty in differentiating cell populations by light microscopy and the much higher number of cells per sample that are analyzed by flow cytometry (Koess and Hamann, 2008; Pilla et al., 2013; Takano et al., 2018). Still, even using flow cytometry, the mAb used can affect the DCC outcomes. We accurately identified PMN, monocyte/ macrophage, and lymphocyte subsets, whereas others evaluating milk DCC by flow cytometry did not use 
Table 2. Percentage of milk PMN, monocyte/macrophage and lymphocyte subsets from healthy quarters [bacteriologically negative with low quarter milk SCC (qSCC); stratum 1], nonspecific mastitis (bacteriologically negative with high qSCC; stratum 2), and noninflammatory

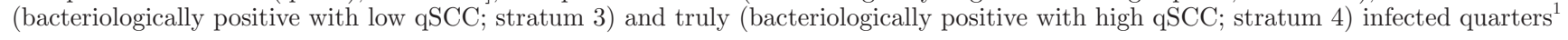

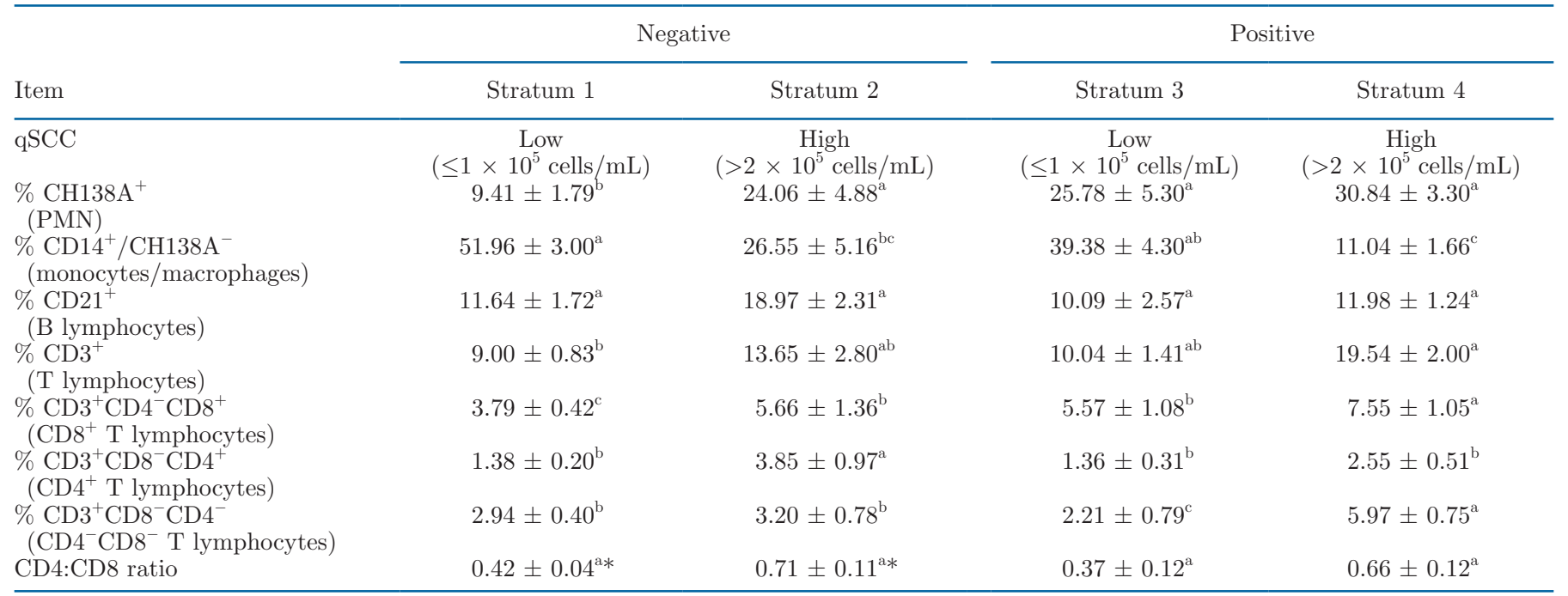

${ }^{\mathrm{a}-\mathrm{c}}$ Different superscripts within a row indicate $P \leq 0.05$.

${ }^{1}$ The results are shown as the mean \pm SEM.

$* P=0.06$.

CD14 and CH138A mAb in combination (Pillai et al., 2001; Rivas et al., 2001; Dosogne et al., 2003; Koess and Hamann, 2008; Schwarz et al., 2011; Pilla et al., 2013). Not doing so can lead erroneous identification of some PMN as monocyte/macrophages, considering that PMN can also express CD14 on their surface (Paape et al., 1996; Sladek et al., 2002; Ibeagha-Awemu et al., 2008). Even worse, some studies did not use a specific $\mathrm{mAb}$ to accurately differentiate and identify many milk cell types (Pillai et al., 2001; Dosogne et al., 2003). Other studies used CD11b mAb to identify PMN or to

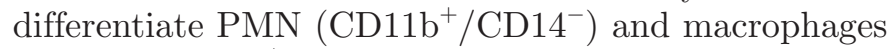
$\left(\mathrm{CD} 11 \mathrm{~b}^{-} / \mathrm{CD}^{+} 4^{+}\right.$; Koess and Hamann, 2008; Schwarz et al., 2011; Pilla et al., 2013) though lymphocytes and macrophages can also express CD11b (Christensen et al., 2001; Duan et al., 2016).

It is well known that the percentage of neutrophils can differentiate between bacteriological statuses of quarter milk samples, even in those with low qSCC (qSCC $\leq 1 \times 10^{5}$ cells $/ \mathrm{mL}$ ), and therefore should be regarded as of utmost importance for the identification of inflamed or infected quarters. Here, we observed that the percentage of milk PMN was lower in healthy quarters compared with the other strata. In contrast to our findings, Pilla et al. (2012) showed that the percentage of PMN from healthy quarters did not statistically differ from bacteriology positive quarters with a low qSCC.

Although there is no consensus on the main leukocyte population in healthy mammary quarters (Dosogne et al., 2003; Schwarz et al., 2011; Pilla et al., 2012; Pilla et al., 2013; Blagitz et al., 2015a; Takano et al., 2018), our study strengthens the idea that milk monocytes/macrophages represent the major leukocyte population in healthy mammary gland, as previously proposed (Sarikaya et al., 2004, 2005; Merle et al., 2007; Damm et al., 2017; Gonçalves et al., 2017). In contrast to our results, Dosogne et al. (2003), Schwarz et al. (2011), and Pilla et al. (2012) described that lymphocytes represent the predominant cell population, which counterposes the higher percentage of monocyte/macrophages in healthy mammary glands and higher percentage of $\mathrm{T}$ cells $\left(\mathrm{CD}^{+}\right)$and $\mathrm{CD} 8^{+} \mathrm{T}$ lymphocytes in the truly infected quarters from our study. In this regard, although previous studies have determined the percentage of lymphocytes in quarter milk samples with distinct SCC, our study allowed us to provide accurate information of distinct lymphocyte subpopulations.

In agreement with our results, $\mathrm{T}$ cells, especially $\mathrm{CD}^{+} \mathrm{T}$ cells, recruitment has been previously reported during IMI (Soltys and Quinn, 1999; Tassi et al., 2013). An increased number of $\gamma \delta \mathrm{T}$ cells, mainly represented here by $\mathrm{CD}^{-} \mathrm{CD} 8^{-} \mathrm{T}$ cells (Nieto Farias et al., 2018) in milk from cows with staphylococcal and streptococcal mastitis, has also been reported (Soltys and Quinn, 1999), which may explain the highest level of this lymphocyte subpopulation in truly infected quarters, mostly caused by streptococci. Therefore, it is difficult to compare the DCC of milk obtained by distinct methods because the type of material of the sample bottle 


\begin{tabular}{|c|c|c|c|}
\hline $\begin{array}{c}\text { Group/ } \\
\text { Leukocyte Population } \\
\end{array}$ & Stratum 2 & Stratum 3 & Stratum 4 \\
\hline $\begin{array}{c}\text { \% CH138A } \\
\text { (PMNLs) }\end{array}$ & $\uparrow$ & $\uparrow$ & $\uparrow$ \\
\hline $\begin{array}{c}\text { \% CD14 }{ }^{+} / \mathrm{CH}^{\prime} 138 A^{-} \\
\text {(Monocytes/Macrophages) }\end{array}$ & $\downarrow$ & - & $\downarrow$ \\
\hline $\begin{array}{c}\% \text { CD21 }^{+} \\
\text {(B lymphocytes) }\end{array}$ & - & - & - \\
\hline $\begin{array}{c}{\text { \% } \mathrm{CD3}^{+}}^{\text {(T Lymphocytes) }}\end{array}$ & - & - & $\uparrow$ \\
\hline $\begin{array}{c}\% \mathrm{CD3}^{+} \mathrm{CD4}^{-\mathrm{CDB}^{+}} \\
\left(\mathrm{CD8}^{+} \mathrm{T}^{2} \text { Lymphocytes }\right)\end{array}$ & $\uparrow$ & $\uparrow$ & $\uparrow \uparrow$ \\
\hline $\begin{array}{l}\%_{\mathrm{CD3}^{+} \mathrm{CD8}^{-} \mathrm{CD4}^{+}} \\
\left(\mathrm{CD4}^{+} \mathrm{T}^{2} \text { Lymphocytes }\right)\end{array}$ & $\uparrow$ & - & - \\
\hline $\begin{array}{c}\text { \% CD3 }{ }^{+} \mathrm{CDB}^{-\mathrm{CD}^{-}} \\
\text {(CD4- CD8 } \\
\end{array}$ & - & $\downarrow$ & $\uparrow$ \\
\hline
\end{tabular}

Figure 3. Fluctuations of each leukocyte population in quarters with nonspecific mastitis [bacteriologically negative with high quarter milk SCC (qSCC); stratum 2], and noninflammatory (bacteriologically positive with low qSCC; stratum 3) and truly (bacteriologically positive with high qSCC; stratum 4) infected quarters in comparison to healthy quarters (bacteriologically negative with low qSCC). (-) not affected; single up arrow $=$ higher than healthy quarters; double up arrow $=$ higher than all groups; down arrow $=$ lower than healthy quarters.

and method of preparation, including centrifugation steps, could affect the leukocyte populations (Schröder and Hamann, 2005), beyond the effect of distinct milk fractions on somatic milk cell populations (Sarikaya et al., 2005). Moreover, one should keep in mind that the immune response between quarters in cows is not an independent process (Blagitz et al., 2015b), and that is the reason why interdependence of udder quarters within cows was considered in the statistical analysis.

The most prominent result of the present study is that the nonspecific mastitis was associated with a higher percentage of milk $\mathrm{CD} 4^{+} \mathrm{T}$ lymphocytes. While the study size is relatively limited, the higher percentage of $\mathrm{CD}^{+} \mathrm{T}$ lymphocytes associated with nonspecific masti-

Table 3. Milk PMN functions from healthy quarters [bacteriologically negative with low quarter milk SCC (qSCC); stratum 1], nonspecific mastitis (bacteriologically negative with high qSCC; stratum 2), and noninflammatory (bacteriologically positive with low qSCC; stratum 3) and truly (bacteriologically positive with high qSCC; stratum 4) infected quarters ${ }^{1}$

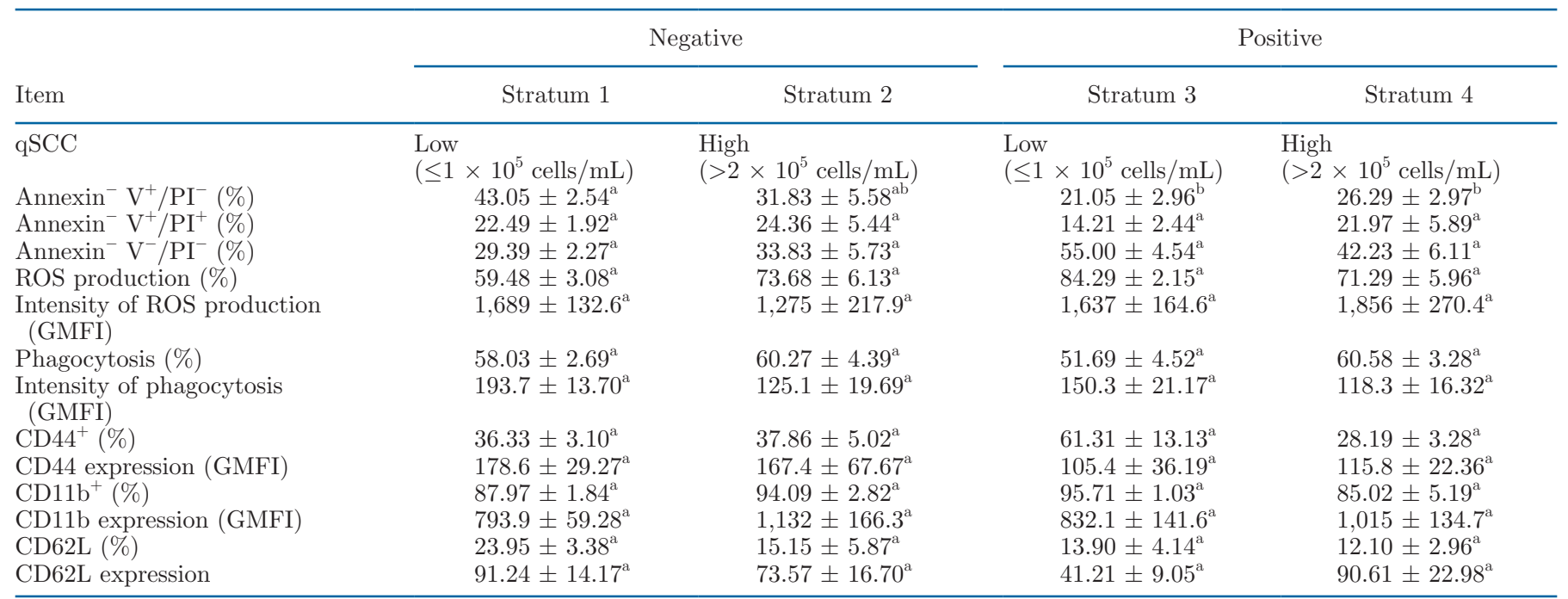

\footnotetext{
a,b Different superscripts within a row indicate $P \leq 0.05$.

${ }^{1}$ The results are shown as the mean \pm SEM. PI $=$ propidium iodide; ROS $=$ reactive oxygen species; GMFI $=$ geometric mean fluorescence
} intensity. 
tis, strengthening the role of milk $\mathrm{CD} 4^{+} \mathrm{T}$ lymphocytes for mammary gland immunity. We hypothesize that the increase in milk $\mathrm{CD} 4^{+} \mathrm{T}$ lymphocytes can present a key role in reducing the number of viable bacteria in the milk and can consequently decrease the likelihood of isolating the pathogen through milk culture, suggesting the capability of the immune system to overcome the infection. In fact, $\mathrm{CD} 4^{+} \mathrm{T}$ lymphocytes have been associated with clearance activity against several bacterial pathogens (Dunkley et al., 1994; Rivas et al., 2000). These cells can also capture bacteria efficiently from dendritic cells through a process termed transphagocytosis, allowing to kill internalized bacteria in lysosomes (Cruz-Adalia et al., 2017). Rainard et al. (2015) also showed that bovine $\mathrm{CD}^{+}{ }^{+} \mathrm{T}$ lymphocytes can produce either IL-17A and IFN- $\gamma$. The IL-17A is associated with $\mathrm{T}_{\mathrm{H}} 17$ immune response, which is implicated in neutrophil mobilization and immune response modulation and antigen-specific inflammation (Rainard et al., 2013). The $\mathrm{T}_{\mathrm{H}} 17$ immune response also mediates the communication between the immune system and mammary epithelial cells, culminating in the upregulation of genes that encode antimicrobial peptides in bovine mammary epithelial cells, providing an alternative process for killing mastitis pathogens (Bougarn et al., 2011; Tassi et al., 2013). Beyond IL-17A, it is regarded that IFN- $\gamma$, which is associated with an $\mathrm{T}_{\mathrm{H}} 1$ immune response, is essential for the control and elimination of infections by intracellular pathogens, and also plays an important role in protection against extracellular pathogens through its capacity to stimulate $\operatorname{IgG}_{2}$ production. The recognition of antigens by specific antibodies, especially IgG2, is important for the phagocytic capacity of milk neutrophils (Paape et al., 2003). In agreement with our results, Tassi et al. (2013) described that the resolution of IMI by Streptococcus uberis was associated with an increase in milk IL-17A levels that was preceded by a temporal increase in the levels of $\mathrm{CD} 4^{+} \mathrm{T}$ lymphocytes. Tassi et al. (2013) also showed that the IL-17A levels concurred with the inversion of the $\mathrm{CD} 4^{+}$to $\mathrm{CD} 8^{+}$ ratio. In our study, there is also a tendency toward a higher $\mathrm{CD} 4^{+}$to $\mathrm{CD} 8^{+}$ratio in quarters with nonspecific mastitis compared with healthy quarters. Thus, our results suggest that an increase in milk $\mathrm{CD} 4^{+} \mathrm{T}$ cells may help in overcoming IMI in dairy cows, although further (longitudinal) studies are needed. Therefore, we believe that if we map the responses of animals that have mounted successful pathogen-host immune response, we may uncover potential novel targets that provide a basis for the development of alternative therapeutics (Souza et al., 2019).

Neutrophils have a shorter lifespan than other immune cells (Bassel and Caswell, 2018). Resolution of an inflammation entails the removal of PMN and their toxic products from the site of infection by a process called apoptosis. Thus, apoptosis is a most sophisticated way of removing PMN at the site of infection, supporting the resolution of inflammation (Rainard and Riollet, 2006; Piepers et al., 2009). If this process fails, it results in a chronic, persistent inflammation; severe tissue damage; or both (Van Oostveldt et al., 2002; Rainard and Riollet, 2006; Piepers et al., 2009). In fact, the process of removing apoptotic neutrophils by macrophages termed efferocytosis produces anti-inflammatory cytokines and resolves inflammation (Bassel and Caswell, 2018). Regarding that, here we report that the qSCC of infected quarters with either low and high qSCC were statistically different from healthy mammary glands, which can be related to the inhibition of neutrophil apoptosis to survive and cause disease (Boutet et al., 2004; Sladek et al., 2005). In contrast, the behavior of apoptotic PMN from nonspecific mastitis was not statistically different from healthy mammary quarters, suggesting resolution of inflammation.

\section{CONCLUSIONS}

Our study strongly supports the crucial role of DCC in the diagnosis of mastitis, as monocytes/macrophages represent the major leukocyte type in healthy mammary glands, in contrast to an increase of PMN and T cells, especially $\mathrm{CD}^{+} \mathrm{T}$ cells, in truly infected mammary quarters. Furthermore, an increase in milk $\mathrm{CD} 4^{+}$ $\mathrm{T}$ cells was associated with nonspecific mastitis, suggesting an increase in this leukocyte subpopulation is correlated with low bacterial shedding and an increased likelihood of resolution of the infection. Future longitudinal studies are required to assess the role of milk $\mathrm{CD} 4^{+}$lymphocytes as a predictive marker for bacteriological cure of IMI. Thus, studying quarters or cows that have mounted a successful pathogen-host immune response will improve our understanding of mammary gland immunity, potentially creating opportunities for the development of novel targets that could confer protective immunity against IMI.

\section{ACKNOWLEDGMENTS}

The authors are grateful for financial support from the São Paulo State Research Foundation (FAPESP Project no. 2009/50672-0; Brazil) and Coordinator for the Improvement of Higher Education Personnel (CAPES; Brazil). FNS is also grateful to FAPESP to his fellowship (process no. 2014/23189-4). PVT, AMMPDL, and MBH are indebted to National Council for Scientific and Technological Development (CNPq) to their fellowships. The authors have not stated any conflicts of interest. 


\section{REFERENCES}

Andersen, S., I. R. Dohoo, O. Riekerink, H. Stryhn, and Mastitis Research Workers' Conference. 2010. Diagnosing intramammary infections: Evaluating expert opinions on the definition of intramammary infections using conjoint analysis. J. Dairy Sci. 93:29662975. https://doi.org/10.3168/jds.2009-2726.

Bansal, B. K., J. Hamann, N. T. Grabowski, and B. Singh. 2005. Variation in the composition of selected milk fraction samples from healthy and mastitic quarters, and its significance for mastitis diagnosis. J. Dairy Res. 72:144-152. https://doi.org/10.1017/ S0022029905000798.

Bassel, L. L., and J. L. Caswell. 2018. Bovine neutrophils in health and disease. Cell Tissue Res. 371:617-637. https://doi.org/10.1007/ s00441-018-2789-y.

Batista, C. F., F. N. Souza, K. R. Santos, E. M. Ramos Sanchez, L. C. Reis, H. G. Bertagnon, M. G. Blagitz, R. C. Gomes, A. P. Lage, M. B. Heinemann, and A. M. M. P. Della Libera. 2018. RPhycoerythrin-labeled Mannheimia haemolytica for the simultaneous measurement of phagocytosis and intracelular reactive oxygen species production in bovine blood and bronchoalveolar lavage cells. Vet. Immunol. Immunopathol. 196:53-59. https://doi.org/10 .1016/j.vetimm.2017.12.004.

Blagitz, M. G., F. N. Souza, C. F. Batista, L. F. F. Azevedo, N. R. Benites, P. A. Melville, S. A. Diniz, M. X. Silva, J. P. Haddad, M. B. Heinnemann, M. M. O. P. Cerqueira, and A. M. M. P. Della Libera. 2015a. The neutrophil function and lymphocyte profile of milk from bovine mammary glands infected with Streptococcus dysgalactiae. J. Dairy Res. 82:460-469. https://doi.org/10.1017/ S0022029915000308.

Blagitz, M. G., F. N. Souza, C. F. Batista, L. F. F. Azevedo, E. M. Ramos Sanchez, S. A. Diniz, M. X. Silva, J. P. Haddad, and A. M. M. P. Della Libera. 2017. Immunological implications of bovine leucemia vírus infection. Res. Vet. Sci. 114:109-116. https://doi .org/10.1016/j.rvsc.2017.03.012.

Blagitz, M. G., F. N. Souza, C. F. Batista, S. A. Diniz, L. F. F. Azevedo, M. X. Silva, J. P. Haddad, M. B. Heinemann, M. M. O. P. Cerqueira, and A. M. M. P. Della Libera. 2015b. Flow cytometric analysis: Interdependence of healthy and infected udder quarters. J. Dairy Sci. 98:2401-2408. https://doi.org/10.3168/jds.2014-8727.

Blagitz, M. G., F. N. Souza, B. P. Santos, C. F. Batista, A. C. Parra, L. F. F. Azevedo, P. A. Melville, N. R. Benites, and A. M. M. P. Della Libera. 2013. Function of milk polymorphonuclear neutrophil leukocytes in bovine mammary glands infected with Corynebacterium bovis. J. Dairy Sci. 96:3750-3757. https://doi.org/10 $.3168 /$ jds.2012-6370.

Bougarn, S., P. Cunha, F. B. Gilbert, A. Harmache, G. Foucras, and P. Rainard. 2011. Staphylococcal-associated molecular patterns enhance expression of immune defense genes induced by IL-17 in mammary epithelial cells. Cytokine 56:749-759. https://doi.org/ 10.1016/j.cyto.2011.09.020.

Boutet, P., D. Boulanger, L. Gillet, A. Vanderplasschen, R. Closset, F. Bureau, and P. Lekeux. 2004. Delayed neutrophil apoptosis in bovine subclinical mastitis. J. Dairy Sci. 87:4104-4114. https://doi .org/10.3168/jds.S0022-0302(04)73553-5.

Brazil. 2008. Law no. 11794, Oct. 8, 2008. Diário Oficial da União, Brasília.

Christensen, J. E., S. O. Andreasen, J. P. Christensen, and A. R. Thomsen. 2001. CD11b expression as a marker to distinguish between recently activated effector $\mathrm{CD} 8^{+} \mathrm{T}$ cells and memory cells. Int. Immunol. 13:593-600. https://doi.org/10.1093/intimm/13.4 .593 .

Cruz-Adalia, A., G. Ramirez-Santiago, J. Osuna-Pérez, M. Torres-Torresano, V. Zorita, A. Martínez-Riaño, V. Boccasavia, A. Borroto, G. Martínez del Hovo, J. M. González-Granado, B. Alarcón, F. Sánchez-Madrid, and E. Veiga. 2017. Conventional CD4 ${ }^{+} \mathrm{T}$ cells present bacterial antigens to induce cytotoxic and memory CD $8^{+}$ T cell responses. Nat. Commun. 8:1591. https://doi.org/10.1038/ s41467-017-01661-7.
Damm, M., C. Holm, M. Blaabjerg, M. N. Bro, and D. Schwarz. 2017. Differential somatic cell count-A novel method for routine mastitis screening in the frame of Dairy Herd Improvement testing programs. J. Dairy Sci. 100:4926-4940. https://doi.org/10.3168/ jds.2016-12409.

Della Libera, A. M. M. P., F. N. de Souza, C. F. Batista, B. P. Santos, L. F. F. Azevedo, E. M. Ramos Sanchez, S. A. Diniz, M. X. Silva, J. P. Haddad, and M. G. Blagitz. 2015. Effect of bovine leukemia virus infection on milk neutrophil function and the milk lymphocyte profile. Vet. Res. (Faisalabad) 46:2. https://doi.org/10.1186/ s13567-014-0125-4.

Di Rienzo, J., F. Casanoves, M. Balzarini, L. Gonzalez, M. Tablada, and C. W. Robledo. 2018. InfoStat version 2018. Grupo InfoStat, FCA, Universidad Nacional de Córdoba, Argentina. Accessed Feb. 28, 2018. http://www.infostat.com.ar.

Dosogne, H., F. Vangroenweghe, J. Mehrzad, A. M. Massart-Leën, and C. Burvenich. 2003. Differential leukocyte count method for bovine low somatic cell count milk. J. Dairy Sci. 86:828-834. https://doi .org/10.3168/jds.S0022-0302(03)73665-0.

Duan, M., S. P. Steinfort, D. Smallwood, M. Hew, W. Chen, M. Ernst, L. B. Irving, G. P. Anderson, and M. L. Hibbs. 2016. CD11b immunophenotyping identifies inflammatory profiles in the mouse and human lungs. Mucosal Immunol. 9:550-563. https://doi.org/ 10.1038/mi.2015.84.

Dunkley, M. L., R. L. Clancy, and A. W. Cripps. 1994. A role for $\mathrm{CD} 4^{+} \mathrm{T}$ cells from orally immunized rats in enhanced clearance of Pseudomonas aeruginosa from the lung. Immunology 83:362-369.

Gonçalves, J. L., R. L. Lyman, M. Hockett, R. Rodriguez, M. V. Dos Santos, and K. L. Anderson. 2017. Using milk leukocyte differentials for diagnosis of subclinical bovine mastitis. J. Dairy Res. 84:309-317. https://doi.org/10.1017/S0022029917000267.

Hasui, M., Y. Hirabayashi, and Y. Kobayashi. 1989. Simultaneous measurement by flow cytometry of phagocytosis and hydrogen peroxide production of neutrophils in while blood. J. Immunol. Methods 117:53-58. https://doi.org/10.1016/0022-1759(89)90118-X.

Ibeagha-Awemu, E. M., J. W. Lee, A. E. Ibeagha, and X. Zhao. 2008. Bovine CD14 gene characterization and relationship between polymorphisms and surface expression on monocytes and polymorphonuclear neutrophils. BMC Genet. 9:50. https://doi.org/10.1186/ 1471-2156-9-50.

Koess, C., and J. Hamann. 2008. Detection of mastitis in the bovine mammary gland by flow cytometry at early stages. J. Dairy Res. 75:225-232. https://doi.org/10.1017/S0022029908003245.

Makovec, J. A., and P. L. Ruegg. 2003. Results of milk samples submitted for microbiological examination in Wisconsin from 1994 to 2001. J. Dairy Sci. 86:3466-3472. https://doi.org/10.3168/jds .S0022-0302(03)73951-4.

Merle, R., A. Schröder, and J. Hamann. 2007. Cell function in the bovine mammary gland: A preliminary study on interdependence of healthy and infected udders quarters. J. Dairy Res. 74:174-179. https://doi.org/10.1017/S002202990600238X.

National Mastitis Council. 1999. Laboratory Handbook on Bovine Mastitis. National Mastitis Council Inc., Madison, WI.

Nieto Farias, M. V., F. N. Souza, P. A. Lendez, L. Martínez-Cuesta, K. R. Santos, A. M. M. P. Della Libera, M. C. Ceriani, and G. L. Dolcini. 2018. Lymphocyte proliferation and apoptosis of lymphocyte subpopulations in bovine leukemia virus-infected dairy cows with high and low proviral load. Vet. Immunol. Immunopathol. 206:41-48. https://doi.org/10.1016/j.vetimm.2018.10.012.

Oliver, S. P., R. N. González, J. S. Hogan, B. M. Jayarao, and W. E. Owens. 2004. Microbiological Procedures for the Diagnosis of Bovine Udder Infection and Determination of Milk Quality. National Mastitis Council, Verona, WI.

Oliver, S. P., S. E. Murinda, and B. M. Jayarao. 2011. Impact of antibiotic use in adult dairy cows on antimicrobial resistance of veterinary and human pathogens: A comprehensive review. Foodborne Pathog. Dis. 8:337-355. https://doi.org/10.1089/fpd.2010.0730.

Paape, M. J., E-.M. Liluis, P. A. Wiitanen, M. P Kontio, and R. H. Miller. 1996. Intramammary defense against infectious induced by Escherichia coli in cows. Am. J. Vet. Res. 57:477-482. 
Paape, M. J., D. D. Bannerman, X. Zhao, and J. W. Lee. 2003. The bovine neutrophil: Structure and function. Vet. Res. 34:597-627. https://doi.org/10.1051/vetres:2003024.

Piepers, S., S. De Vliegher, K. Demeyere, B. N. Lambrecht, A. de Kruif, E. Meyer, and G. Opsomer. 2009. Technical note: Flow cytometric identification of bovine milk neutrophils and simultaneous quantification of their viability. J. Dairy Sci. 92:626-631. https://doi.org/10.3168/jds.2008-1393.

Pilla, R., M. Malvisi, G. G. M. Snel, D. Schwarz, S. König, C.-P. Czerny, and R. Piccinini. 2013. Differential cell count as an alternative method to diagnose dairy cow mastitis. J. Dairy Sci. 96:1653-1660. https://doi.org/10.3168/jds.2012-6298.

Pilla, R., D. Schwarz, S. König, and R. Piccinini. 2012. Microscopic differential cell counting to identify inflammatory reactions in dairy cow quarter milk samples. J. Dairy Sci. 95:4410-4420. https: //doi.org/10.3168/jds.2012-5331.

Pillai, S. R., E. Kunze, L. M. Sordillo, and B. M. Jayarao. 2001. Application of differential inflammatory cell count as a tool to monitor udder health. J. Dairy Sci. 84:1413-1420. https://doi.org/10.3168/ jds.S0022-0302(01)70173-7.

Pinzón-Sánchez, C., and P. L. Ruegg. 2011. Risk factors associated with short-term post-treatment outcomes of clinical mastitis. J. Dairy Sci. 94:3397-3410. https://doi.org/10.3168/jds.2010-3925.

Pyörälä, S. 2003. Indicators of inflammation in the diagnosis of mastitis. Vet. Res. 34:565-578. https://doi.org/10.1051/vetres:2003026.

Rainard, P., P. Cunha, S. Bougarn, A. Fromageau, C. Rossignol, F. B. Gilbert, and P. Berthon. 2013. T helper 17-associated cytokines are produced during antigen-specific inflammation in the mammary gland. PLoS One 8:e63471. https://doi.org/10.1371/journal .pone.0063471.

Rainard, P., P. Cunha, M. Ledresseur, C. Staub, J. L. Touzé, F. Kempf, F. B. Gilbert, and G. Foucras. 2015. Antigen-specific mammary inflammation depends on the production of IL-17A and IFN- $\gamma$ by bovine $\mathrm{CD}^{+} \mathrm{T}$ lymphocytes. PLoS One 16:10:e0137755. https:// doi.org/10.1371/journal.pone.0137755.

Rainard, P., and C. Riollet. 2006. Innate immunity of the bovine mammary gland. Vet. Res. 37:369-400. https://doi.org/10.1051/vetres: 2006007.

Rivas, A. L., F. W. Quimbly, O. Coksaygan, L. Olmstead, and D. H. Lein. 2000. Longitudinal evaluation of $\mathrm{CD}^{+}$and $\mathrm{CD} 8^{+}$peripheral blood and mammary gland lymphocytes in cows experimentally inoculated with Staphylococcus aureus. Can. J. Vet. Res. 64:232-237.

Rivas, A. L., F. W. Quimby, J. Blue, and O. Coksaygan. 2001. 2000. Longitudinal evaluation of bovine mammary gland health status by somatic cell counting, flow cytometry, and cytology. J. Vet. Diagn. Invest. 13:399-407. https://doi.org/10.1177/104063870101300506.

Santos, B. P., F. N. Souza, M. G. Blagitz, C. F. Batista, H. G. Bertagnon, S. A. Diniz, M. X. Silva, J. P. A. Haddad, and A. M. M. P. Della Libera. 2017. Blood and milk polymorphonuclear leukocyte and monocyte/macrophage functions in naturally caprine arthritis encephalitis virus infection in dairy goats. Vet. Immunol. Immunopathol. 188:21-26. https://doi.org/10.1016/j.vetimm.2017.04.009.

Sarikaya, H., C. Prgomet, M. W. Pfaffl, and R. M. Bruckmaier. 2004. Differentiation of leukocytes in bovine milk. Milchwissenschaft 59:586-589.

Sarikaya, H., C. Werner-Misof, M. Atzkern, and R. M. Bruckmaier. 2005. Distribution of leukocyte populations, and milk composition, in milk fractions of healthy quarters in dairy cows. J. Dairy Res. 72:486-492. https://doi.org/10.1017/S0022029905001317.

Schepers, A. J., T. J. G. M. Lam, Y. H. Schukken, J. B. M. Wilmink, and W. J. A. Hanekamp. 1997. Estimation of variance components for somatic cell counts to determine threshold for uninfected quarters. J. Dairy Sci. 80:1833-1840. https://doi.org/10.3168/jds .S0022-0302(97)76118-6.

Schröder, A. C., and J. Hamann. 2005. The influence of technical factors on differential cell count in milk. J. Dairy Res. 72:153-158. https://doi.org/10.1017/S0022029905000804.
Schukken, Y. H., D. J. Wilson, F. Welcome, L. Garrison Tikofsky, and R. N. Gonzalez. 2003. Monitoring udder health and milk quality using somatic cell counts. Vet. Res. 34:579-596. https://doi.org/10 1051/vetres:2003028.

Schwarz, D., U. S. Diesterbeck, K. Failing, S. König, K. Brügemann, M. Zschöck, W. Wolter, and C. P. Czerny. 2010. Somatic cell counts and bacteriological status in quarter foremilk samples of cows in Hesse, Germany - A longitudinal study. J. Dairy Sci. 93:5716-5728. https://doi.org/10.3168/jds.2010-3223.

Schwarz, D., U. S. Diesterbeck, S. König, K. Brügemann, K. Schlez, M. Zschöck, W. Wolter, and C. P. Czerny. 2011. Flow cytometric differential cell counts in milk for the evaluation of inflammatory reactions in clinically healthy and subclinically infected bovine mammary glands. J. Dairy Sci. 94:5033-5044. https://doi.org/10 $.3168 / j \mathrm{jds} .2011-4348$.

Sladek, Z., D. Rysanek, and M. Faldyna. 2002. Activation of phagocytes during initiation and resolution of mammary gland injury induced by lipopolysaccharide in heifers. Vet. Res. 33:191-204. https://doi.org/10.1051/vetres:2002007.

Sladek, Z., D. Rysanek, H. Ryznarova, and M. Faldyna. 2005. Neutrophil apoptosis during experimentally induced Staphylococcus aureus mastitis. Vet. Res. 36:629-643. https://doi.org/10.1051/ vetres:2005023.

Soltys, J., and M. T. Quinn. 1999. Selective recruitment of T-cell subsets to the udder during staphylococcal and streptococcal mastitis: Analysis of lymphocyte subsets and adhesion molecule expression. Infect. Immun. 67:6293-6302.

Souza, F. N., A. F. Cunha, D. L. S. O. Rosa, M. V. A. Brito, A. S. Guimarães, L. C. Mendonça, G. N. Souza, A. P. Lage, M. G. Blagitz, A. M. M. P. Della Libera, A. M. B. Heinemann, and M. M. O. P. Cerqueira. 2016. Somatic cell count and mastitis pathogen detection in composite and single or duplicate quarter milk samples. Pesqui. Vet. Bras. 36:811-818. https://doi.org/10.1590/ s0100-736x2016000900004.

Souza, F. N., E. M. R. Sanchez, A. M. M. P. Della Libera, and M. B. Heinemann. 2019. Letters to the editor: A comment on "Control of bovine mastitis in the $21^{\text {st }}$ century: Immunize or tolerize? Res. Vet. Sci. 26:20-21.

Stevens, M., S. Piepers, K. Supré, J. Dewulf, and S. De Vliegher. 2016. Quantification of antimicrobial consumption in adult cattle on dairy herds in Flanders, Belgium, and associations with udder health, milk quality, and production performance. J. Dairy Sci. 99:2118-2130. https://doi.org/10.3168/jds.2015-10199.

Takano, P. V., M. G. Blagitz, C. S. Mira, C. F. Batista, A. M. M. P. Della Libera, and F. N. Souza. 2018. Estudo comparativo das diferentes técnicas empregadas na contagem diferencial de leucócitos no leite. Pesqui. Vet. Bras. 38:773-778. https://doi.org/10.1590/ 1678-5150-pvb-5252.

Taponen, S., L. Salmikivi, H. Simojoki, M. T. Koskinen, and S. Pyörälä. 2009. Real-time polymerase chain reaction-based identification of bacteria in milk samples from bovine clinical mastitis with no growth in conventional culturing. J. Dairy Sci. 92:26102617. https://doi.org/10.3168/jds.2008-1729.

Tassi, R., T. N. McNeilly, J. L. Fitzpatrick, M. C. Fontaine, D. Reddick, C. Ramage, M. Lutton, Y. H. Schukken, and R. N. Zadoks. 2013. Strain-specific pathogenicity of putative host-adapted and nonadapted strains of Streptococcus uberis in dairy cattle. J. Dairy Sci. 96:5129-5145. https://doi.org/10.3168/jds.2013-6741.

Van Oostveldt, K., M. J. Paape, H. Dosogne, and C. Burvenich. 2002. Effect of apoptosis on phagocytosis, respiratory burst and CD18 adhesion receptor expression of bovine neutrophils. Domest. Anim. Endocrinol. 22:37-50. https://doi.org/10.1016/S0739 $-7240(01) 00115-1$. 